2019 TheoLogica

An International Journal for Philosophy of Religion and Philosophical Theology

S. I. THE SON OF GOD

DOI: https://doi.org/10.14428/thl.v2i3.18413

\title{
The Son of God and Trinitarian Identity Statements
}

\author{
MATTHEW OWEN \\ Gonzaga University \\ owen@gonzaga.edu
}

JOHN ANTHONY DUNNE

Bethel Seminary

j-dunne@bethel.edu

\begin{abstract}
Classical Trinitarians claim that Jesus - the Son of God-is truly God and that there is only one God and the Father is God, the Spirit is God, and the Father, Son, and Spirit are distinct. However, if the identity statement that 'the Son is God' is understood in the sense of numerical identity, logical incoherence seems immanent. Yet, if the identity statement is understood according to an 'is' of predication then it lacks accuracy and permits polytheism. Therefore, we argue that there is another sense of 'is' needed in trinitarian discourse that will allow the Christian to avoid logical incoherence while still fully affirming all that is meant to be affirmed in the confession 'Jesus is God.' We suggest a sense of 'is' that meets this need.
\end{abstract}

Keywords: Trinity, Monotheism, Christology, Identity Statements, ThreeIn-One Problem

Christians claim that Jesus is God. Aristotle claimed that 'is' is used in many ways (Physics, 185a22). Those who agree with the Christian confession and Aristotle will naturally wonder: In what sense of 'is' is Jesus God? Is the Son of God the one true God according to an 'is' of numerical identity, or merely according to an 'is' of predication? In order to give a precise answer, another sense of 'is' is needed in trinitarian discourse. We intend to demonstrate this need and to present a sense of is that meets the need.

In the first section of this article a common objection to Classical Trinitarianism that focuses on the claim that 'Jesus is God' is used to demonstrate the need for another sense of $i$. In the second section we present a sense of $i$ s that satisfies the need-an 'is' of predication in the strong sense. When the Christian's confession 
that 'Jesus is God' is understood in terms of an 'is' of predication in the strong sense, the objection dissipates while the significance of the Christian's confession remains. Subsequently, we briefly discuss the Nicene Creed, after which we give an in-depth analysis of key passages of Scripture discussing the deity of the Son. The rationale for blending Christian analytic theology with biblical scholarship in this article is twofold.

First, we assume that the Christian Scriptures must fundamentally guide Christian analytic theology, and that such guidance by divine revelation is a distinguishing mark of analytic theology vis-à-vis philosophy of religion (see McCall 2015, chap. 2). Given that, the second reason is to meet the objective of demonstrating that our thesis is consistent with what Scripture teaches about the divine nature of the Son. This is an important prerequisite for the project of developing a satisfying metaphysical model of the Trinity. After all, the theologian who misunderstands the identity statements of Classical Trinitarianism in a sense that is too strong will likely take on too heavy a burden. And the theologian who misunderstands the identity statements in a sense that is too weak will likely produce a model that fails to account for the identity claims made by orthodox Christianity. Thus the Christian analytic theologian would do well to secure as much clarity as one can about the identity statements that the Christian is obliged by Scripture to endorse. That is our present goal.

To be clear, however, the reader of this article expecting a metaphysical model explaining the metaphysical mysteries of the Trinity will be thoroughly disappointed. In this article no such model is given, and at the end mysteries will remain. This is no point against the present work nor the doctrine of the Trinity any more than insoluble metaphysical mysteries of our own consciousness is a point against the reality of our consciousness (cf. Heil 2019). Our focus is specifically identity statements and the logical coherence of Christianity's identity statements when properly understood. We want to clarify a sense of 'is' that allows Christians to affirm as accurately and profoundly as possible that Jesus is God while being logically consistent with other foundational doctrines. ${ }^{1}$ When all is said and done, we will have a sense of 'is' that sharpens trinitarian discourse and

\footnotetext{
${ }^{1}$ Much has been written by contemporary philosophers of religion and philosophical theologians pertaining to identity statements and the Trinity (see e.g. van Inwagen 1988, Rea 2003, Merricks 2006, Hughes 2009, Kleinschmidt 2016 \& 2018). Our claim here is not that our articulation of trinitarian identity statements is the only or even the best articulation, which would be beyond the scope of a single research article. The aim of this work is to make explicit one possible way that the doctrine of the Trinity, and specifically the divine identity of the Son, can be faithfully and coherently articulated.
} 
allows one to more accurately confess the true deity of each person of the one triune God.

\section{Common Objection}

Classical Trinitarianism (for brevity CT) maintains there is one God, and that the Father is God, the Son is God, the Spirit is God, and the three are distinct. In a presentation at the LA Theology Conference entitled 'How to be a Monotheistic Trinitarian,' Dale Tuggy articulated how a Muslim monotheist might object to the coherence of CT based on the Christian's confession that Jesus is God:

The Muslim ... fastens on any proof text which allegedly shows that "Jesus is God." She adds that he's obviously not the same god as the one he calls "Father." Is this obvious? Yes it is, if each is a god. Note that in our view, the Father and Son differ, and it is self-evident that numerically identical things can't differ. If any $x$ and $y$ have actually differed, it follows that $x$ is not $y$ and $y$ is not $x$-that is, $x$ and $y$ are truly two. Again this is common sense ... (Tuggy 2014a, 4) ${ }^{2}$

The objection assumes CT claims the persons of the Trinity are numerically identical to God, and alleges that this cannot be given their distinctness. Grounds for such reasoning include Leibnitz's law of the indiscernibility of identicals, which says two things that have different properties cannot be identical to one another, and the transitivity of identity, which says if one thing is identical to a second thing that is identical to a third thing then the first is identical to the third.

The alleged problem for CT can be put in the following way. CT claims: (1) monotheism, (2) each person of the Trinity is numerically identical to God, and (3) each person is distinct. Given these claims the worry arises. If $1 \& 2$ are true, then 3 must be false on the basis of the transitivity of identity. Yet, if $2 \& 3$ are true, 1 must be false on the basis of Leibnitz's law. But if $1 \& 3$ are true, then 2 must be false on the basis of Leibnitz's law. In sum, proponents of CT seem saddled with the necessity of denying one of their claims, given that the set of claims seems logically inconsistent. However, this logical inconsistency dissipates when CT's claims are more accurately understood.

\footnotetext{
${ }^{2}$ Italics original. A condensed reading of the paper can be found online (see Tuggy 2014b).
} 


\section{The Meaning of 'is'}

The objection above reads the propositions 'Jesus is God' and the 'Father is God' according to an 'is' of numerical identity. According to Leibnitz's law of the indiscernibility of identicals, numerically identical entities have all and only the same properties as one another. ${ }^{3}$ If we learn that the Evening Star is (of numerical identity) the planet Venus, and so is the Morning Star, then the Evening Star and Morning Star must have all and only the same properties as one another. And 'they' are not distinct but are the one planet Venus. Likewise, if monotheism is true, and if Jesus is God and the Father is God in the sense of numerical identity, it follows that the Son would be numerically identical to the Father. Consequently, there could be nothing true of the Son that is not true of the Father, and vice versa. In other words, views akin to Sabellianism would follow. Yet, if things are true of the Son that are not true of the Father, such as the Son died for our sins, then they are distinct. But if they are distinct, yet numerically identical to God, they must be two distinct gods since they are not identical to one another. Hence, polytheism would follow. Indeed, if CT is making its claims regarding the persons being God in the sense of an is of numerical identity, then CT "strongly and steadily seems contradictory," as Tuggy suggests. ${ }^{4}$

However, identity statements are complex and there are different types of identity statements. We can say that ' $x$ is $y$ ' in the sense of numerical identity. In this sense, Xi Jinping is the President of the People's Republic of China; the current President and $\mathrm{Xi}$ Jinping are numerically identical. But we can also say that ' $\mathrm{x}$ is $\mathrm{y}^{\prime}$ according to an 'is' of predication. In this sense, $\mathrm{Xi}$ Jinping is human. However, Kipchoge Keino is human too, and likewise for billions of other persons. So one can see how the door is left open for polytheism if we merely say 'Jesus is God' in this weak sense of predication. Consequently, the Christian needs a sense in which she can make an identity statement that has more plasticity than numerical identity statements, but more rigidity than mere predication. Of aid to us will be the concept of a substance. According to Michael Loux:

Aristotle and those following him have called [some] concrete particulars [i.e. wholes that exist] substances ... The Greek word for which 'substance' is our English translation is 'ousia,' and it does a better job of expressing the force of

\footnotetext{
${ }^{3}$ For a helpful introduction to Leibnitz's law of the indiscernibility of identicals and his other law, the identity of indiscernibles, see Beebee, Effingham, and Goff 2011, 114-115. See also Moreland and Craig 2003, 194-196.

4 Tuggy 2014a, 2. Cf. idem 2014b, 2:45-3:30; 2016, section 4.
} 
calling something a substance. 'Ousia' is a noun derived from the Greek verb for 'to be.' The force, then of calling concrete particulars substances is to identify them as genuine beings, or full-fledged realities rather than mere constructions out of lower-level things. (Loux 2006, 114)

Substances are intrinsically unified entities that are fundamental in the sense that they are not aggregates composed out of lower level, more fundamental, substances (Inman 2018, chap. 3). As Alston $(2002,181)$ has pointed out, Aristotle makes a critical distinction between a primary substance and a secondary substance that is relevant to trinitarian theology.

A substance - that which is called a substance most strictly, primarily, and most of all-is that which is neither said of a subject nor in a subject, e.g. the individual man or the individual horse. The species in which the things primarily called substances are, are called secondary substances, as also are the genera of these species. For example, the individual man belongs in a species, man, and animal is a genus of the species; so these-both man and animal-are called secondary substances. (Aristotle Categories, 2a13-19)

The contemporary metaphysical term 'natural kind' corresponds with what Aristotle refers to as a secondary substance (Alston 2002, 182). What is most important for our discussion is a primary substance, which is an existing unified individual entity, not merely a kind.

Some primary substances have distinct aspects that do not exist apart from the whole, and these aspects are often called 'integral parts' because they do not exist apart from the substance and their nature is the same as that of the substance. ${ }^{5}$ There are many examples of substances with such parts that we could use to illustrate an important point about identity statements, but let us use the example of Adam and suppose he was the only human person God ever created and is thus the only human substance. The phrase 'Adam's right hand is human' would be a statement according to an 'is' of predication. But given that Adam is the only human God ever created, the 'is' of predication can be intended in a sense that refers to a primary substance, as opposed to merely a kind. The words 'is human' would then refer not merely to a category that the subject is a member of, but to a particular substance that there is only one of. We can compare this stronger sense of an 'is' of predication to the weaker sense in the above identity statements

\footnotetext{
${ }^{5}$ See Brown 2005, chap. 6. Integral parts are also sometimes referred to as 'inseparable parts' or 'proper parts.'
} 
regarding $\mathrm{X}_{\mathrm{i}}$ Jinping and Kipchoge Keino, where the 'is human' merely refers to the kind, or category, of substance Xi and Keino are a member of. In Aristotle's terminology, the 'is' of predication in the identity statement about Adam's right hand refers to a primary substance (i.e. a unified existing whole), whereas the 'is' of predication in the identity statement about Jinping and Keino refers to a secondary substance (i.e. kind or category).

In light of this, one can distinguish two senses of an 'is' of predication, one pertaining to primary substance and one pertaining merely to secondary substance (or kind). The 'is' of predication pertaining to primary substance we can call an is of predication in the strong sense. The 'is' of predication pertaining to secondary substance we can call an is of predication in the weak sense. We now have three senses of is:

Numeric Identity: ' $x$ is $y$ ' $=$ df. $x$ has all and only the same properties as $y$.

Predication in the weak sense: ' $x$ is $y$ ' $=\mathrm{df} . x$ is of the kind $y$.

Predication in the strong sense: ' $x$ is $y$ ' $=\mathrm{df}$. $x$ is an integral aspect of the primary substance $y$ and the nature of $x$ is that of $y$.

Recall that the above objection regarding the Christian's claim that Jesus is God was based on the idea that the 'is' in the identity statement 'Jesus is God' is an 'is' of numerical identity and likewise for the identity statements 'the Father is God' and 'the Spirit is God.' Assuming monotheism and given the transitivity of identity, if the Son is God, and the Father is God, and the Spirit is God according to an 'is' of numerical identity then it is logically impossible for the three persons to be distinct. And this would be the case even if the persons were modes or relations; they would not be distinct modes or relations but would rather be identical modes or relations. Consequently there would be no triunity in God because God would not be tripersonal if the Father, Son, and Spirit were identical (see section 1). ${ }^{6}$ However, the 'is' of predication in the strong sense allows the identity statements of CT to avoid this logical conundrum while also affirming that each person of the Trinity is a particular substance-i.e. the one true God-and truly the nature of that substance.

At this point, it will be helpful to succinctly articulate what CT's identity statements in reference to God amount to in the terminology being employed. Not only will this elucidate the fact that the alleged logical incoherence dissipates, it

\footnotetext{
${ }^{6} \mathrm{Cf}$. Aquinas (ST 1a 28.3sc): "Therefore, if the relations were not really distinguished from each other, there would be no real trinity in God, but only an ideal trinity, which is the error of Sabellius."
} 
will also address a concern relevant to divine simplicity. The concern is that there is a significant difference between God and the substances that have been referred to in the examples given thus far to introduce the terminology being used; for Aristotle referred to a horse and humans have also been referred to. But these substances have parts, whereas God does not. Given this, it is important to note that the terminology we are using can be and most often is employed in reference to everyday substances that often have parts, but this is not necessarily so. Each sense of 'is' distinguished above can be used in reference to substances with or without parts. Just as the metaphysical term 'substance' often refers to an entity with parts (e.g. a horse) but can also fittingly refer to a metaphysically simple being such as God, the same is true for the senses of 'is' that we have hitherto explicated. Using these different senses of 'is,' CT's identity statements in reference to God can be summarized as follows.

Monotheism Only one divine substance exists.

Triunity God is tripersonal. The Trinity is God, according to an 'is' of numerical identity and according to an 'is' of predication in the strong sense.

Son is God The Son is God, according to an 'is' of predication in the strong sense. Thus the nature of the Son is that of the one divine substance.

Father is God The Father is God, according to an 'is' of predication in the strong sense. Thus the nature of the Father is that of the one divine substance.

Spirit is God The Holy Spirit is God, according to an 'is' of predication in the strong sense. Thus the nature of the Spirit is that of the one divine substance.

Distinct Persons While each person-Father, Son, and Spirit-is the one divine substance according to an 'is' of predication in the strong sense, they are not numerically identical to each other.

If CT claims each person is God according to an 'is' of predication in the strong sense, not numeric identity, the alleged logical inconsistency discussed above in section 1 does not arise. One cannot add up the persons and get multiple gods, nor does the transitivity of identity collapse the distinctness of the persons, and the door is not left open for polytheism. The reality affirmed is that there is one triune 
God who is (of numerical identity) Father, Son, and Spirit, and each distinct person is (of predication in the strong sense) God.

Our above articulation of CT's claims might sound similar to what Bohn (2011) has argued for in 'The Logic of the Trinity.'7 According to Bohn, "... God is identical with the Father, the Son, and the Holy Spirit collectively, but not with each one of them distributively" $(2011,363)$. There is similarity in that we both agree that the best way to understand the statements 'the Son is God,' 'the Father is God,' and 'the Spirit is God' is not according to an 'is' of numerical identity. And Bohn thinks these statements should be understood according to an 'is' of predication (see Bohn 2011, 367-368). However, Bohn does not make the distinction between an 'is' of predication in the strong sense and an 'is' of predication in the weak sense. Without this distinction, the statement 'the Son is God' according to an 'is' of predication is not clearly affirming all that the Christian wants to affirm. Thus we have distinguished between two senses of 'is' of predication and proposed that the claim 'the Son is God' be understood according to an 'is' of predication in the strong sense, which avoids logical incoherence but also preserves the full profundity of the statement. Furthermore, assuming Bohn intends to commit to a model of the Trinity, it is worth reiterating that our thesis is not meant to propose or commit to a model. Our thesis is only about the nature of trinitarian identity statements, not what metaphysical explanation accounts for how these statements are true.

Assuming that the 'is' of numerical identity is the strongest sense of is, some might object to our thesis and claim that the Christian ought to affirm Jesus is God according to an 'is' of numerical identity since it is the strongest sense of 'is.' Wanting to affirm the deity of the Son in the strongest possible sense, we are in full agreement with the sentiment of this objection. But our response is that an 'is' of predication in the strong sense is the strongest sense of 'is' by which we can confess that 'Jesus is God' without logically entailing a denial of other core doctrines, and the Trinity itself.

Although an 'is' of numeric identity might be the most rigid sense of 'is,' it is not logically possible for one to consistently say that Jesus is numerically identical to God and so is the Father, likewise regarding the Spirit, and yet they are distinct. Consider the words of Stephen Holmes:

So the Father is not the Son, and Father is not the Spirit, and the Son is not the Spirit, and the Father begets and the Son is begotten, and the Spirit proceeds from the Father and the Son-this language is particular and hypostatic. All other

\footnotetext{
${ }^{7}$ Cf. Moreland and Craig 2003, 589-595.
} 
language, without exception, qualification, or reserve, refers to the unrepeatable divine essence. (Holmes 2014, 43)

Everything that can be said of the divine essence is true of each person. Nevertheless, each person of the Godhead has distinctness even though they are of the same substance. The Father is not the Son, nor is the Son the Father, nor are they the Holy Spirit. The persons are really distinct, and without such distinctness the triunity of the one God collapses.

Therefore, given that the Father, Son, and Spirit are distinct it is not fitting to say each is numerically identical to God, which would entail a denial of their distinctness and given monotheism a denial of the triunity of God. Yet, since there is only one God and thus one divine substance, let the Christian not merely predicate divinity of the persons via an 'is' of predication in the weak sense. Let the Christian rather affirm the deity of the persons in the strongest possible sense, which is an 'is' of predication in the strong sense. In doing so she will affirm that Jesus, the Son of God, is the one divine substance without denying the additional truths that the Father and Spirit are also that substance and yet distinct.

Lastly, it is important to note that an 'is' of numerical identity might not be strong enough in one way to affirm what the confession 'Jesus is God' is meant to affirm. For as the phrase 'numerical identity' suggests, an 'is' of numerical identity pertains more evidently to quantification than substance and nature. The statement 'A is B' according to an 'is' of numerical identity means A and B are one thing. You could tell me that: $(S)$ a set of auto parts in my garage is numerically identical to my car (C). But this would not tell me whether the set is a substance or a substance of a particular nature or whether the auto parts in the set are the same nature as $C$. However, an 'is' of predication in the strong sense pertains to substance and nature, which is what is of concern in trinitarian identity statements regarding the persons. The Christian's claim 'the Son is God' is a claim regarding substance and nature. It is a claim that the Son is the one divine substance and his nature is truly divine.

Having introduced a sense of 'is' that allows CT to avoid the alleged logical inconsistency discussed in section 1, one might wonder whether the proposed solution is consistent with Church tradition and more importantly, Scripture. In the next section we briefly discuss the Nicene Creed before turning to a more thorough analysis of biblical passages concerning the divinity of the Son.

\section{The Nicene Creed}


The first ecumenical council in Nicaea began the creed with an affirmation of monotheism and subsequently affirmed the deity of Christ:

We believe in one God the Father all-powerful, Maker of all things ... And in one Lord Jesus Christ, the Son of God, the Only-begotten, begotten from the Father, that is from the substance of the Father, God from God, light from light, true God from true God, begotten not made, consubstantial [i.e. homoousios] with the Father, through whom all things came to be ... And in the Holy Spirit. (Pelikan and Hotchkiss 2003, 159)

Not only is the creed clearly affirming monotheism, but the distinctness of the persons is apparent as well. Additionally, the creed affirms the deity of the Father and Son. Since a contradiction would follow from such affirmations if what is meant is that the Father and Son are each numerically identical to God, charity suggests that we try to understand what the authors meant while keeping in mind that they, like us, would not obviously contradict themselves. Only if there is no viable consistent reading can we conclude that they meant what is clearly contradictory.

Central to the creed's affirmation of Christ's deity and a faithful interpretation of the creed is the term 'consubstantial', or homoousios, meaning same substance (Muller 1985, 139). This term ' ... indicates the fullness of the indivisible ousia, or substance, of the Godhead in each of the divine persons and implies the essential coinherence (circumincessio, q.v.) of the three persons' (Muller 1985, 139-140). What the creed employs the term to affirm is nothing less than that there is one divine substance, which is predicated of each person. But there is no apparent reason to interpret usage of this term to be suggesting that the persons individually are numerically identical to the triune God. Rather, what it seems the creed is affirming is an identity of primary substance (hence the term 'homoousios' meaning same substance), which is what the 'is' of predication in the strong sense affirms. $^{8}$

It appears that the Nicene Creed uses the term homoousios to indicate, what the Athanasian Creed affirms in the following way:

... the Godhead of the Father, the Son, and the Holy Spirit is one, their glory equal, their majesty coeternal. Such as the Father is, such is the Son, such also the Holy

\footnotetext{
${ }^{8}$ One might argue that the term 'homoousios' itself could possibly be used in reference to secondary substance. But given the context of a creed that explicitly affirms monotheism (i.e. only one divine substance exists) at the outset, thus emphasizing the affirmation, we think the term is most reasonably interpreted here as a reference to a primary substance.
} 
Spirit ... Thus the Father is God, the Son is God, and the Holy Spirit God; and yet there are not three gods, but there is one God. (Pelikan and Hotchkiss 2003, 676677)

The claim is that there is one divine being, the Godhead, which is the Father, Son, and Spirit. Thus each person is what the Godhead is-namely, the one divine substance. We would say this, according to the language we have been employing here, as follows: there is one divine primary substance, the Godhead, which is (of numeric identity) the Father, Son, and Spirit; therefore, each person is (of predication in the strong sense) the primary substance, God.

We do not see any good reason to think the Nicene Creed says anything that demands one to interpret the authors to be asserting the 'Son is God' or the 'Father is God' or the 'Spirit is God' according to an 'is' of numeric identity. However, given the monotheistic emphasis in the creeds it does not seem best to interpret such assertions according to an 'is' of predication in the weak sense either. Rather it seems best to interpret the assertions according to an 'is' of predication in the strong sense. This is especially clear in light of the use of homoousios. But we shall now turn our attention to Scripture, heeding the words of Barth: "So listen to my last piece of advice, exegesis, exegesis, and yet more exegesis! Keep to the Word, to the Scripture that has been given to us." 9

\section{4. “And the Word was God" (John 1:1)}

The most natural place to start an investigation into scriptural precedent for understanding the claim "Jesus is God" as predication in the strong sense, is with places in the New Testament where Jesus is called God ( $\theta \varepsilon$ cos). Harris has provided the best treatment of this subject to date (Harris 1992). He identifies the following texts as examples and offers a chapter-length treatment of each passage: John 1.1, 1.18, 20.28; Acts 20.28; Romans 9.5; Titus 2.13; Hebrews 1.8-9; 2 Peter 1.1; 1 John 5.20. He concludes that there are varying degrees of probability regarding whether $\theta \varepsilon$ ćs is used in reference to Jesus with each. Among the examples just listed, he regards only two as "certain" (John 1.1 and John 20.28). Among the others he regards half of them to be "very probable" (Romans 9.5, Titus 2.13, Hebrews 1.8, and 2 Peter 1.1), one as "probable" (John 1.18), and the rest as "possible" (Acts

\footnotetext{
${ }^{9}$ Karl Barth, formal farewell at Bonn, Germany, February 10 1935, quoted in Busch 1975, 259. See Sanders $(2005,169-170)$ on the relevance of biblical studies.
} 
20.28, Hebrews 1.9, 1 John 5.20). ${ }^{10}$ For our purposes we are not concerned to work through each of these texts. Rather, we will look at one in particular as an example of the NT phenomenon of referring to Jesus as God (i.e. Өcós), since this will help us demonstrate that the divine identity of Jesus taught in the NT can be fittingly understood in terms of predication in the strong sense, as opposed to numerical identity. As Harris is quick to remind us, you cannot find a straightforward

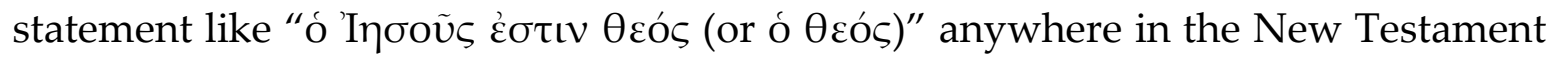

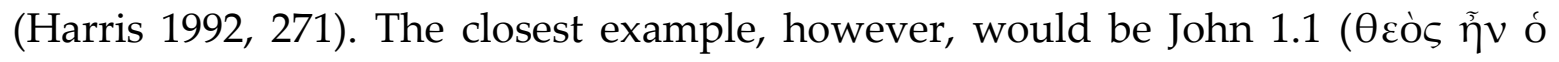
$\lambda$ ó $\gamma$ os). ${ }^{11}$ Since the statement is in fact an example of grammatical predication, we will address it here briefly. ${ }^{12}$

The Gospel of John famously begins with the following words, which have been discerned by many to be latent with trinitarian potential:

In the beginning was the Word, and the Word was with God, and the Word was God (John 1.1, our trans.).

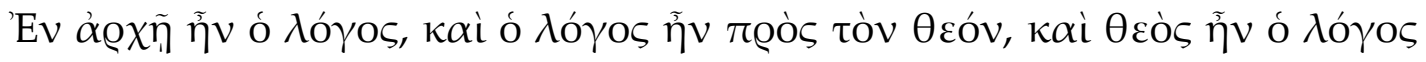
(John 1.1, NA ${ }^{28}$ ).

There are a number of issues here that we will not be able to address, such as the origin and significance of the use of $\lambda$ ó $\gamma \mathrm{os}$. Although the biblical background of

\footnotetext{
${ }^{10}$ Harris 1992, 271. Before his concluding chapter he also has a short chapter called "Other Texts," where he addresses some texts that have been suggested as examples, but which he contends are not likely (see Harris 1992, 255-68).

${ }^{11}$ Even though here $\theta \varepsilon$ có is predicated of the logos asarkos, there is personal continuity between the logos asarkos and the logos ensarkos, as the prologue and indeed the rest of the Gospel make clear (cf. esp. John 1.14). Thus, the logos asarkos should not be understood as a mere personification which was otherwise technically impersonal, similar to divine Wisdom (cf. Proverbs 8). The key difference

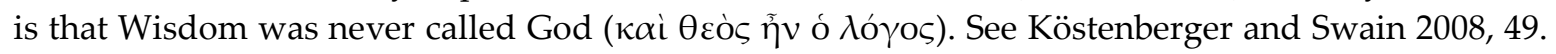
Furthermore, Köstenberger and Swain note that, although the term $\lambda$ ó $\gamma \circ$ s is never again used with reference to Jesus outside of the Prologue - instead there is a predominance of filial kinship language (i.e. "Son") - nevertheless there is a "paradigm of traits" between what is said of the Word and what is said of Jesus throughout the entirety of the Gospel. See Köstenberger and Swain 2008, 113-14.

${ }^{12}$ The next likely passage where $\theta \varepsilon$ ó $\varsigma$ would be predicated of Christ grammatically would be

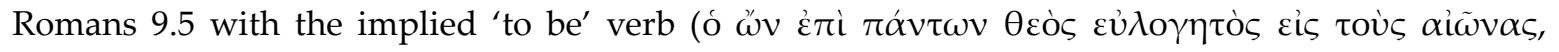
$\dot{\alpha} \mu \eta v v)$, but that is only if the Christological interpretation is correct, which is highly controversial. For those who take the Christological reading, see, e.g., Wright 2015 [2002], 535-37; Moo 1996, 56468. For those who reject the Christological reading, see, e.g., Dunn 1988, 535-36. Given that Romans 9.5 cannot be considered with certainty an example of $\theta \varepsilon$ ó $\varsigma$ predicating Christ, we will keep our focus on John 1.1.
} 


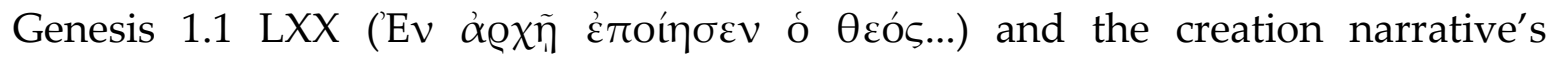
emphasis on God creating through divine speech seems most compelling to us (see, e.g., Bauckham 2007, 240-42), nothing that we have to say here depends upon that reading. ${ }^{13}$ Our focus is strictly on both the distinction between God and the Word, and then also how that fact relates to the Word being God.

John's Gospel is famous not only for its "high christology" and lofty statements about Jesus, but also for its clear and consistent distinction between Christ and God through the Father-Son relationship. ${ }^{14}$ As such, there is no way to equate the Father with the Son as being numerically identical in the Gospel. ${ }^{15}$ Even in John 10.30, where Jesus says "I and the Father are one," it is important to note that the Greek word for "one" is neuter rather than masculine ( $\varepsilon v$ instead of $\varepsilon(\varsigma)$ ). The neuter form preserves the distinction between the two, noting their unity of purpose and will. ${ }^{16}$ So the distinction between the two is clear in John's Gospel, and we could look to other places to make this point as well regarding oneness yet distinction, such as the so-called "high priestly prayer" of Jesus in John $17,{ }^{17}$ and so on.

The reason why this is important to point out is because, in John's Gospel, as in most of the New Testament, $\theta$ cós is a way of referring to the Father (on this see esp.

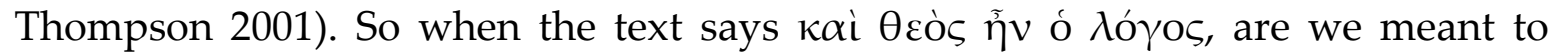
understand that the Word, which the text tells us took on flesh in John 1.14 as Jesus Christ, is here in John 1.1 being called the Father? Is the text asserting that the Word and God are numerically identical?

One way to answer ' $\mathrm{No}^{\prime}$ is to point out that, since the noun $\theta \varepsilon$ cos is anarthrous (meaning that it lacks the article) the text is merely saying that the Word was "a god." This view has been championed by Jehovah's Witnesses (cf. New World Translation of the Holy Scriptures), but it improperly assumes that anarthrous nouns

\footnotetext{
${ }^{13}$ For discussion on possible backgrounds and potential interpretations among Jews and Greeks at the time, see Klink 2016, 87-89.

${ }^{14}$ On the relationship between the Father and the Son in the Gospel of John, see Akala 2014.

${ }^{15}$ As Wallace $(1996,268)$ rightly affirms, "The Fourth Gospel is about the least likely place to find modalism in the NT."

${ }^{16}$ Bauckham 2007, 250-51; Thyen 2005, 499; Beasley-Murray 1999, 174; Carson 1991, 394-95; Keener 2003, 1:826; Morris 1995, 464-65. Contra Schulz (1983, 153), who states that "eine Einheit des Wesens" is in view here. Note the words of Theodore of Mopsuestia (in Conti 2010, 98) commenting on John 10.30, "In other words, Jesus says, 'I am superior to all just like he is, because I, like him, am the author of creation and I created with him. And so I am equal to him in power. He and I are one in greatness and power. No one can snatch what is mine from my hand or from my Father's hand either."

${ }^{17}$ On this see esp. the treatment of John 17 in Köstenberger and Swain 2008, 166-79.
} 
are necessarily indefinite. As has been pointed out many times, such a position would lead to multiple problems, not least as it pertains to how $\theta \varepsilon$ ó is used anarthrously elsewhere in the Gospel of John, at least fifteen times, with reference to the Father. ${ }^{18}$

Syntactically, we are not simply dealing with an anarthrous $\theta \varepsilon$ ó in John 1.1, we

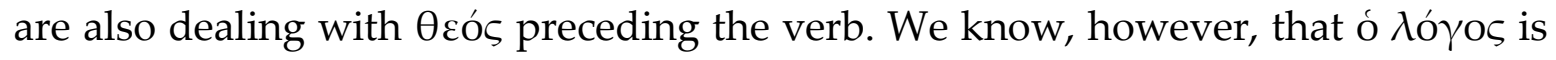
the subject, not merely because of the article, but because contextually ó $\lambda$ ó $\gamma$ os is the subject of the preceding two clauses. Indeed, the whole prologue of John's

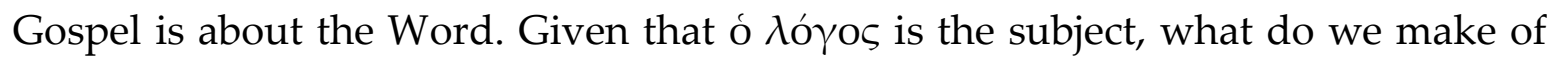
the anarthrous $\theta \varepsilon$ ós preceding the copula $\tilde{\eta} v$ ? As Wallace points out, the majority of anarthrous predicate nominatives that precede the verb are normally qualitative. ${ }^{19}$

The reason why this bit of grammar is important is because it preserves the distinction between the person normally designated $\theta \varepsilon$ co $\varsigma$ in John, i.e. the Father, and the person John calls the Word (who will later become incarnate in Christ).

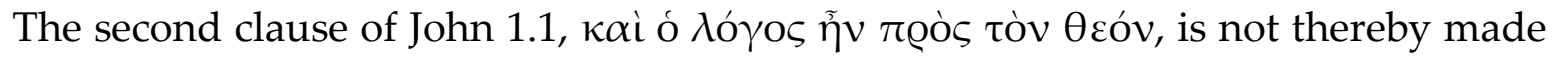

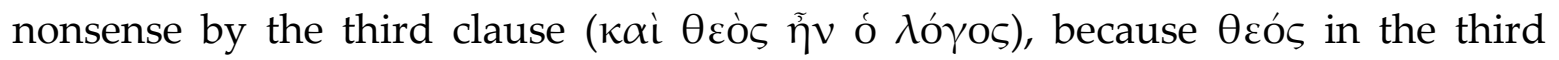
clause, unlike the second, is not in reference to the person designated $\theta \varepsilon$ cos. Thus, the statement "the Word was God" is not an equivalence of two persons (i.e. the persons are not numerically identical). John $1.1 \mathrm{~b}$ is qualified by $1.1 \mathrm{c}$ to avoid one kind of misunderstanding, which is then further clarified in 1.2, reiterating the main point from $1.1 \mathrm{~b}$, to again avoid misunderstanding. ${ }^{20}$

${ }^{18}$ Here are all of the places in the Gospel of John where you can find anarthrous uses of $\theta \varepsilon$ ó 5 that refer to the Father (fifteen times total): John 1.6, 12-13, 18; 3.2, 21; 6.45; 8.54; 9.16, 33; 13.3; 16.30; $19.7 ; 20.17(\mathrm{x} 2)$. There are a few things to note about this list. Most of the examples of anarthrous $\theta \varepsilon$ ćs are part of prepositional phrases, though several are not (e.g. John 1.12; 1.18; 6.45; 8.54; 19.7; 20.17 [x2]). This list includes some verses where both anarthrous and articular forms occur. John 1.18 is only counted once even though $\theta \varepsilon$ ó $s$ appears anarthrously twice; the first anarthrous form is

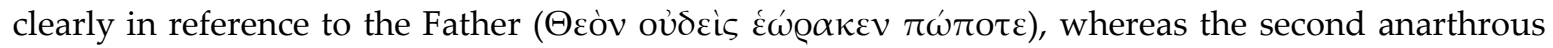

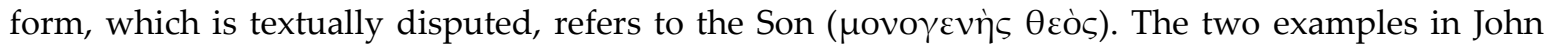
10.34-35 of anarthrous plural forms are obviously not included in the list ( $\theta \varepsilon$ có $\dot{\varepsilon} \sigma \tau \varepsilon ; \theta \varepsilon o u ̀)$. John

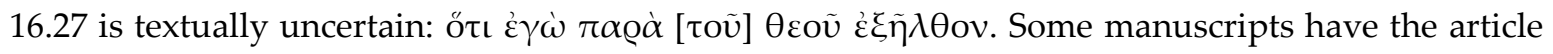
(e.g. $\left.\mathrm{C}^{3}, \mathrm{~W}\right)$ and some do not (e.g. $\left.\mathrm{P}^{5}, \mathrm{x}^{*}, 2, \mathrm{~A}\right)$. UBS ${ }^{5}$ gives the articular reading a $\mathrm{C}$ grade, and Metzger $(1994,212)$ explains that "The balance of evidence for and against the definite article is so close [. . .]." Given its uncertainty, we have decided not to include it in our list above.

19 Wallace 1996, 269. Cf. also Harris 1992, 67; Köstenberger and Swain 2008, 49-50; Harner 1973.

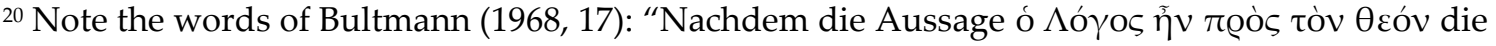
Vorstellung hervorrusen könnte, es handle sich um die Gemeinschaft zweier göttlicher Personen, wird jetzt die Aussage ins entgegenesetzte Extrem getrieben: $\theta \varepsilon \dot{\varsigma} \varsigma \tilde{\eta} v$ ó $\lambda o ́ \gamma o \varsigma$. Aber auch dies wird 
Thus, the word $\theta \varepsilon$ có in John 1.1c, as Harris notes, is about the "genus" of the Word, and thus the predication is "nonreciprocating." ${ }^{21}$ In other words, you cannot reverse the statement and have it make sense. In the earlier example that we used: "Xi Jinping is human" cannot be converted into "human is Xi Jinping." 22 Yet, we want to go a step further and highlight the importance of using the language of strong predication. The Word does not exhaust God without remainder. Within trinitarian discourse we would say that the Word is not numerically identical to the triune God, and is, therefore, distinguishable from God. ${ }^{23}$ Yet, the Word is God, not merely according to second substance, but according to primary substance. Thus, while not numerically identical to God, the Word is the being: God. In other words, "The Word is not who God is," as Köstenberger and Swain affirm, "but he is what God is" (Köstenberger and Swain 2008, 113 n. 8). The Word is not merely divine, but is inseparable from God (even though they are not to be conflated).

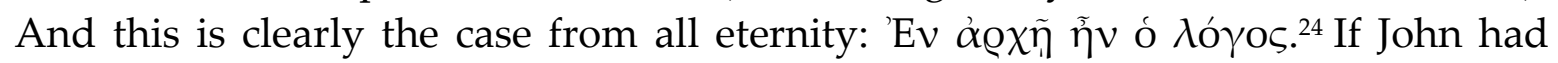
wanted to simply affirm that the Word was God-like, he could have done so quite easily with the adjective $\theta \varepsilon$ ino $_{.}{ }^{25}$ Once again, the Gospel of John is ripe for seeing both the clear distinction between the Father and the Son, and for speaking of the Son as being God in the same sense as the Father is God. In the light of this balance, Martin Hengel $(2008,272)$ concludes, "Thus the Evangelist is on the way toward the Nicene Creed." That is, the theological judgments made here in John 1.1 and elsewhere in the Gospel are on the trajectory that leads to Nicea, which we have already addressed in the preceding section as maintaining an 'is' of predication in

sofort wieder gegen ein Mißverständnis geschützt, indem das eben Gesagte gleichsam revoziert

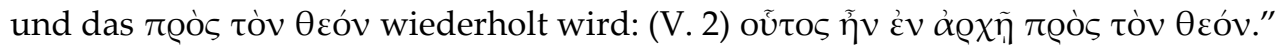

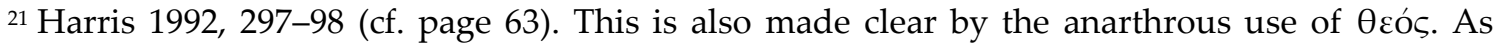

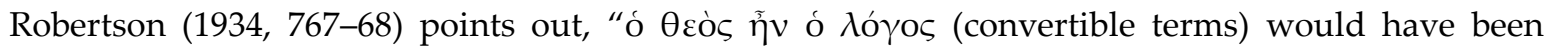
Sabellianism."

${ }^{22}$ Yet, by comparing "God" and "Human" in these examples, we do not wish to convey that "God" is a generic term, which would undermine monotheism.

${ }^{23}$ Cyril of Alexandria: "Because he was 'with God,' we recognize him as another besides the Father, and we believe that the Son exists on his own. But because he 'was God,' we understand him to be of the same substance and to be from him by nature because he is both God and comes forth from God." See Cyril of Alexandria (in Maxwell 2013, 13).

${ }^{24}$ As Augustine notes (Tract. Ev. Jo. 1.11-13; cf. Rettig 1988), the Gospel does not begin by

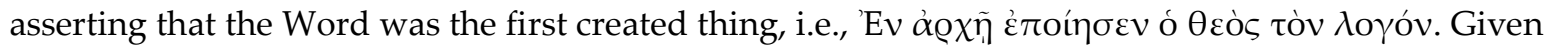
that all created things were made through the Word (John 1.3), Augustine rightly sees this as being incompatible with the teachings of the Arians.

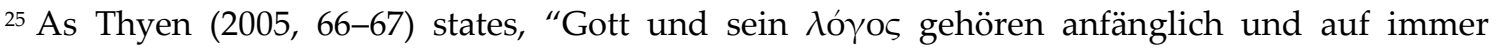
zusammen. Darum ist es gewiß kein Zufall, daß vom $\lambda o ́ \gamma o \varsigma$ nicht mit dem durchaus geläufigen Adjektiv $\theta \varepsilon i ̃ o \varsigma$ gesagt wird, er sei göttlichen Wesens." 
the strong sense. Indeed, the poetic conclusion of Tillman in his commentary on John 1.1 regarding the nature of the Word is fitting to cite here as a conclusion to this section. The Word is

Not a shadowy idea, not a half-hypostasized Word, not a power and quality of God, not a midway-being between God and the world, that only in an improper sense can one name 'God.' No, light from light, true God from true God, same being with the eternal Father. (Tillman 1931, 53)26

\section{The "Christ Hymn" of Philippians}

After looking at one example from among a notable selection of New Testament passages that refer to Jesus as $\theta \varepsilon \varsigma,{ }^{27}$ we will now turn to look at an example where the issue of Jesus's equality with God is directly addressed. Although the term $\theta \varepsilon$ có is not grammatically predicated of Jesus (as in John 1.1), we are nevertheless singling out the example of the "Christ Hymn" of Philippians because

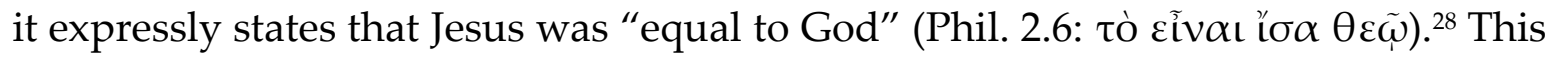
is therefore another helpful text for our purposes because it brings up the issue of numerical identity and distinction of persons once again, and we can reaffirm the idea that trinitarian discourse ought to make use of an 'is' of predication when saying "Jesus is God."

Philippians 2.6-11, often regarded as a great Christological hymn of the early church, tells of the humiliation and exaltation of Christ. There are a number of interesting questions to ask about the Philippian text, which we simply will not be able to address. The most significant question that will be left aside is the text's possible literary prehistory. ${ }^{29}$ This will be avoided because it will not affect our

\footnotetext{
${ }^{26}$ Our translation of the original German: "Nicht eine schattenhafte Vorstellung, nicht halb hypostasiertes Wort, nicht eine Kraft und Eigenschaft Gottes, nicht ein Mittelwesen zwischen Gott und Welt, das man nur in einem uneigentlichen Sinne Gott nennen darf. Nein, Licht vom Lichte, wahrer Gott vom wahren Gott, gleichen Wesens mit dem ewigen Vater."

${ }^{27}$ Of course, in the case of John 1.1 it is the Word that is directly addressed. Note our caveat in footnote 11.

${ }^{28}$ Of course, John 5.18 states something very similar ("̌́ov $\varepsilon \alpha v \tau o ̀ v ~ \pi o เ \tilde{\omega} v \tau \tilde{\omega} \theta \varepsilon \tilde{\omega}$ ), yet we are focusing on the text in Philippians for two reasons. First, it allows us to see this idea expressed prior to, and outside of, Johannine influence (since we have already addressed John 1.1 above). Second, it might be worth noting that in John the statement is made polemically with a negative connotation as part of the motivation for those conspiring to kill Jesus. In Philippians, at least, it is stated positively by someone who affirms it.

${ }^{29}$ On this, see Lohmeyer 1964, 90-99; Martin 1967. On the possible Aramaic background of the text, see Grelot 1973, 169-86. For a recent methodology for discerning preformed traditions in
} 
interpretation; whether Paul wrote it is ultimately not relevant for the exegesis of the passage, which is our main concern. Other issues that we will have to ignore for the sake of brevity are its resonance with the cultural context of Philippi, ${ }^{30}$ and the alleged scriptural influences on the text: i.e. Adam, ${ }^{31}$ the Suffering Servant, ${ }^{32}$ etc. Where such questions become relevant is in the proposal that an Adamic background would dismiss the possibility that this text speaks of the personal preexistence of the Son prior to the incarnation in verse 6. This position has been argued by Dunn, but has not been met by much approval. Most scholars rightly recognize that verse 6 refers to the preexistence of the Son. ${ }^{33}$ In its present literary context, the subject of the "hymn" is clearly Christ, as the hymnic section begins with the relative pronoun ós pointing back to Christ Jesus in verse 5 . However, if verse 6 is about a pre-incarnation state, then we ought to refer to the subject as the Son, even though this section does not refer to him as such. Yet the "hymn"

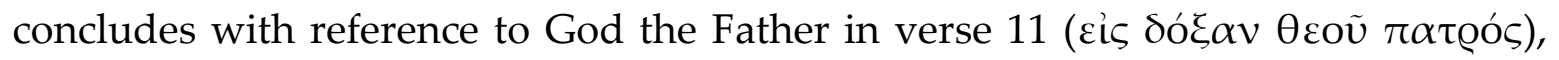
which identifies the subject in integral relationship with the Father. ${ }^{34}$ The Son is the one who, as verses 7-8 point out, would humble himself by taking the form of a slave and by being found in human likeness. Such references contrast sharply with verse 6, which, not only suggest preexistence, but they also cause us to question further the nature of that preexistence. ${ }^{35}$ For our purposes we want to see (a) what is meant by saying that "equality with God" was not considered $\alpha \varrho \pi \alpha \gamma \mu$ óv in verse 6, (b) whether being $\dot{\varepsilon} v \mu о \varrho \varphi \tilde{\eta} \theta \varepsilon$ ov is a way of expressing "equality with God," and (c) how all of this relates to distinctions between the Son and the Father in the passage.

The question to begin this inquiry is discerning what the preincarnate Son, who was in the form of God, did not consider equality with God to be. The word $\alpha \varrho \pi \alpha \gamma \mu$ ó $\varsigma$ has been variously understood. N. T. Wright identified ten different

Paul's letters, see Sumney 2017. On Philippians 2.6-11 in particular, see idem 2017, 28-31, 56-60, 100.

30 See esp. Hellerman 2005; Oakes 2001.

${ }^{31}$ See Dunn 1998, 281-88.

32 See esp. Bauckham 2008, 41-45.

${ }^{33}$ Wright, for one, is an example of someone who holds to both an Adamic background and the Son's preexistence in this text. See Wright 1993, 56-98.

${ }^{34}$ On the "horizontal axis" of divine personal relations in Philippians 2.6-11, see esp. Hill 2015, 77-110. For more on how God is defined by Jesus and how Jesus is defined by God in Paul's letters, see Watson 2000.

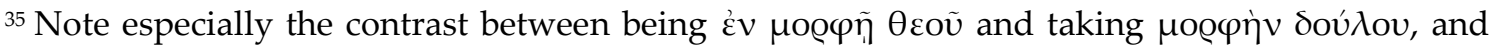

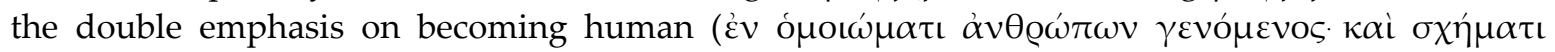

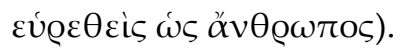


ways that scholars have understood this term in Philippians 2.7 with distinct implications for the exegesis of the passage (Wright 1993, 56-98 [69-82]). However, many regard the influential philological work of Hoover (1971), which Wright utilized and promoted in his study, as settling the matter. The term is here part of a

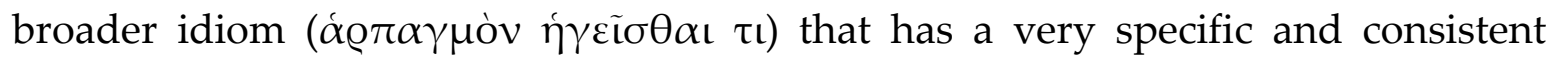
meaning. It is not about snatching or gripping tightly to something someone has or stole, but is rather about "the attitude one will take towards something which one already has and holds and will continue to have and hold, specifically, to the question of whether that attitude will or will not consist in taking advantage of this possessed object" (Wright 1993, 78, emphasis original). This understanding of où $\chi \alpha \varrho \pi \alpha \gamma \mu$ òv

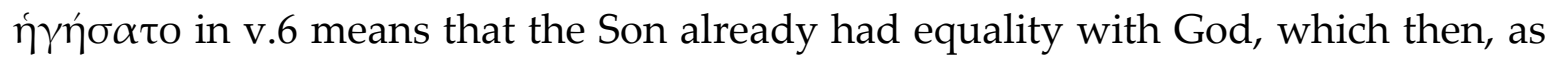
Wright suggests, means that "equality with God" is epexegetical for "being in the form of God." 36 That this is so helps to set up the contrast with verse 7. ${ }^{37}$ Yet, when Paul says that the Son was $\dot{\varepsilon} v \mu о \varrho \varphi \tilde{\eta} \theta \varepsilon$ ov, it could merely refer to outward appearance (or $\delta o ́ \xi \alpha$ ) without referring specifically to ontology. ${ }^{38}$ However, as Hill $(2015,89)$ rightly points out, "the point is the same: Jesus' $\mu о \varrho \varphi \eta$ is the same as

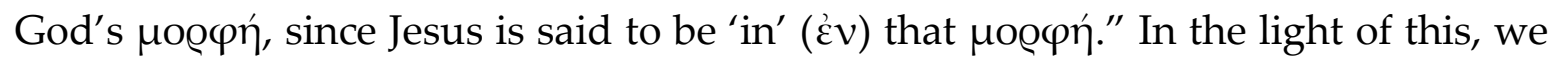

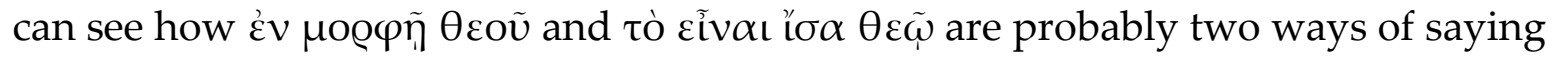
the same thing. ${ }^{39}$ In fact, this is how many early patristic interpreters understood the passage, such as Gregory of Nyssa and Marius Victorinus, etc. ${ }^{40}$

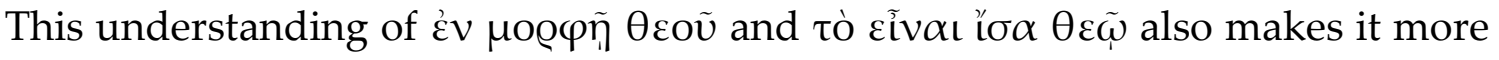

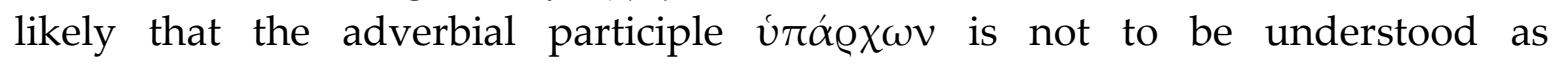

${ }^{36}$ Wright 1993, 83. His grammatical argument for this is that articular infinitives regularly function by pointing back to something previously stated, following BDF §399. However, Burk (2004) has demonstrated that this grammatical point is not likely. Burk contends that this leaves open the possibilities that "being in the form of God" and "being equal with God" are distinct concepts. But it certainly does not necessitate that.

${ }^{37}$ As Friedrich $(1981,152)$ states, “Der Ausdruck „in Gestalt-Gottes-Sein“ wird durch das im Parallelismus dazu stehende "Gott-gleich-Sein“ und has gegensätzliche „Gestalt des Knechtes“ (V. 7) erklärt."

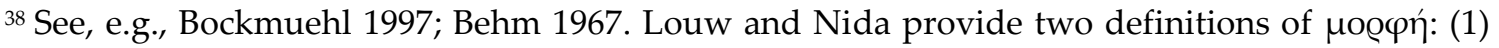
"the nature and character of something, with emphasis upon both the internal and external form 'nature, character' (Louw and Nida §58.2), and (2) 'a visual form of something - 'visual form, appearance'” (§58.15). They opt for interpreting Phil. 2.6 under the first definition.

${ }^{39}$ See, e.g., Silva 2005 (1992), 100-1; Fee 2007, 376-81; idem 1995, 207; Hellerman 2005, 133-35; Wright 1993, 83.

${ }^{40}$ Gregory of Nyssa, Against Eunomius 3.2.147 and Marius Victorinus, Against the Arians I.21-22, as found in Edwards 1999. 
concessive, ${ }^{41}$ as most translations have it, but rather as causal. The Son was not

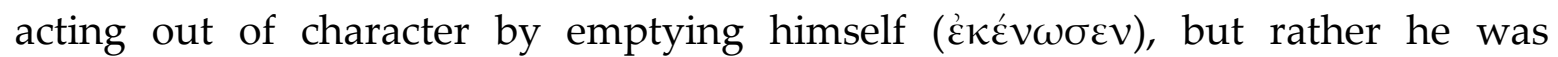
demonstrating what it is to be $\dot{\varepsilon} v \mu \circ \varrho \varphi \tilde{\eta} \theta \varepsilon 0 \tilde{v} .{ }^{42}$ Wright affirms, "incarnation and even crucifixion are to be seen as appropriate vehicles for the dynamic selfrevelation of God." 43 This has implications for the concept of self-emptying, or kenotic Christology, from verse 7. Given the meaning of the idiom behind ov $\chi$

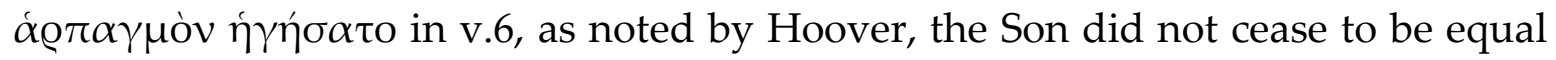
with God but rather took on the form of a slave. It was a kenōsis by addition, not subtraction.

Despite the emphasis on equality and unity from the text, none of this jeopardizes the distinction between the Father and the Son. Note the words of Chrysostom who, in commenting on verse $6 c$, is attempting to dismount Sabellius: "Now equality is not predicated, where there is but one person, for that which is equal hath somewhat to which it is equal. Seeth thou not the substance of two Persons, and not empty names without things? Hearest thou not the eternal preexistence of the Only-begotten?"44

Distinction between the persons can also be found in the assymetrical relationship between the Father and the Son: it is God (ó $\theta \varepsilon$ cos) who exalts the Son (Phil 2.9), and the climax of the whole passage is that the exaltation of the humbled

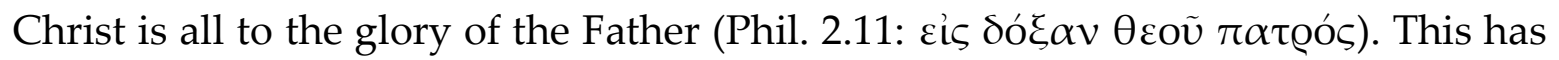

\footnotetext{
${ }^{41}$ Most translations render the participle concessively (cf. NASB; CEB; ESV; NET; NIV; NLT; RSV; NRSV). Grammarians typically take it as concessive as well. See, e.g., Köstenberger, Merkle, and Plummer, 2016, 333; Wallace 1996, 634-35. For the circumstantial view, see, e.g., Fee 1995, 202 n. 40. Among translations that render the participle circumstantially, see KJV; NKJV; ASV; HCSB. No major English translation renders the participle causally.

${ }^{42}$ See, e.g., Bockmuehl 1997, 21-22. Michael J. Gorman contends that the participle should be understood as concessive, but once you see it that way, an additional layer of meaning suggests itself in the direction of a causal participle. He notes that there is an "although $[\mathrm{x}]$ not $[\mathrm{y}]$ but $[\mathrm{z}]$ " pattern in Paul's letters where he speaks of what he could have done but did not do as an apostle in 1 Thess. 2.6-8 and 1 Cor. 9.1-23. The idea is that Paul did not take advantage of being an apostle. As Gorman suggests, this concession actually serves to define what it means to be an apostle. You would not be an apostle if you did take advantage of being an apostle. So just as Paul shows us what true apostleship was like by not taking advantage of his apostleship, so the same is true for Christ, who precisely expresses his divinity by not taking advantage of it. See Gorman 2009, 9-39. See similarly, Hooker 1990, 88-100 (99-100).

${ }^{43}$ Wright 1993, 84. Cf. Barth, CD IV/1, 193: "If, then, God is in Christ, if what the man Jesus does is God's own work, this aspect of the self-emptying and self-humbling of Jesus Christ as an act of obedience cannot be alien to God." However, we do not intend for this to be taken to extremes as some have done with versions of "Rahner's Rule."

${ }^{44}$ Taken from Chrysostom's 'Homily VI' on Philippians 2.5-8 in Schaff 1994, 206-12 (207).
} 
led some to say that whatever lofty statements are made about Christ, even the

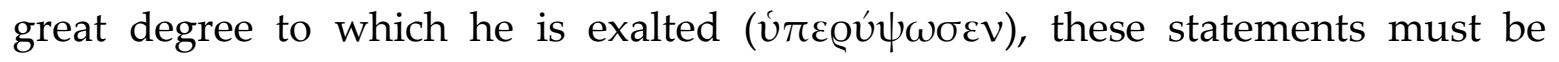
tampered or chastened by the clear distinctions between the persons to such an extent that Jesus' subordination implies a lower ontology than God's. Yet this does not seem possible given the implications of the clear allusions to Isaiah 45.22-23 in Phil 2.10-11 (see below).

\begin{tabular}{|c|c|c|c|}
\hline $\begin{array}{l}\text { Isa. 45.22-23 (LXX; } \\
\text { Göttingen) }\end{array}$ & $\begin{array}{l}\text { Isa. 45.22-23 (Our } \\
\text { Trans.) }\end{array}$ & $\begin{array}{l}\text { Phil. 2.10-11 } \\
\left(\mathrm{NA}^{28}\right)\end{array}$ & $\begin{array}{l}\text { Phil. 2.10-11 (Our } \\
\text { Trans.) }\end{array}$ \\
\hline 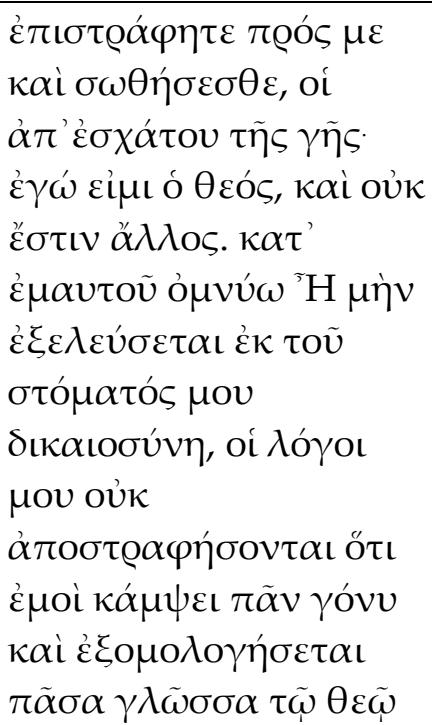 & $\begin{array}{l}\text { Turn to me and you } \\
\text { will be saved, those } \\
\text { from the end of the } \\
\text { earth; I am God and } \\
\text { there is no other. By } \\
\text { myself I swear, } \\
\text { surely justice will go } \\
\text { out from my mouth; } \\
\text { my words will not } \\
\text { be turned away, } \\
\text { because to me every } \\
\text { knee will bow and } \\
\text { every tongue will } \\
\text { confess God. }\end{array}$ & 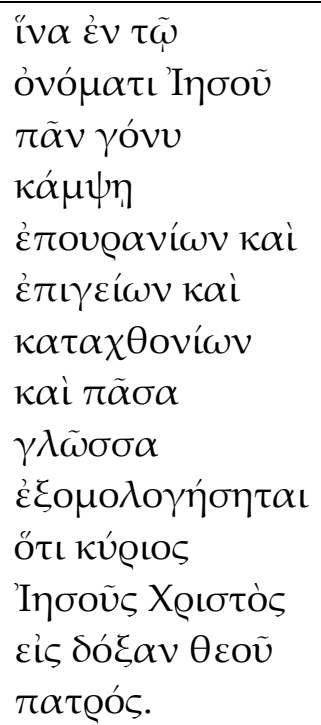 & $\begin{array}{l}\text { In order that at the } \\
\text { name of Jesus every } \\
\text { knee will bow-in } \\
\text { heaven, and on the } \\
\text { earth, and under the } \\
\text { earth - and every } \\
\text { tongue will confess } \\
\text { that Jesus Christ is } \\
\text { Lord, to the glory of } \\
\text { God the Father. }\end{array}$ \\
\hline
\end{tabular}

The allusion is taken from a staunchly monotheistic section of Isaiah (chapters 4048), which should not be missed. YHWH's sovereignty is proclaimed to be universally recognized in Isaiah 45, and now here in Philippians we see Christ's exaltation is the means through which that is accomplished. ${ }^{45}$ As Bauckham (2008, 38) helpfully notes, "monotheism is fulfilled in the revelation of Jesus' participation in the divine identity." What's more, God gives Jesus "the name which is above

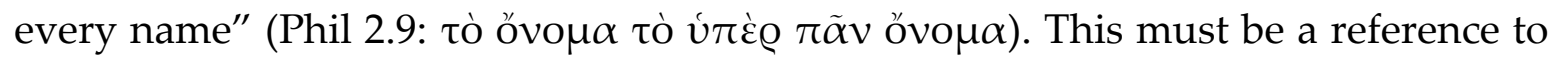
the divine name YHWH itself (cf. Heb. 1.4); no other name comes close to being a fit given the lofty label. ${ }^{46}$ This language should not be qualified by the asymmetry of the Father-Son relation, as Hill rightly argues. The equality and distinction in the text need not be viewed as antithetical concepts operating on the same plane such that one must qualify the other. As Hill helpfully concludes,

\footnotetext{
${ }^{45}$ For more on this phenomenon of ascribing OT texts about YHWH to Jesus, see Capes 1992.

${ }^{46}$ So rightly, e.g., Bauckham 2008, 24-25, 42; Hill 2015, 93.
} 
In terms of his identification with the kú from God (with whom he shares the same form and to whom he is 'equal'). In terms of his relation to the person or agent $\theta \varepsilon$ co $\tau \alpha \tau \tau$ ' God and ordered in such a way that could be labeled 'subordinate.' (Hill 2015, 110)

So the text attests both to his undifferentiation from God (nature) as well as to his differentiation from God (the person). The conclusion to this text, far from diminishing or qualifying the manner in which Christ was "in the form of God" and was "equal with God," brings us right back to the beginning. As unparalleled language of Christ's uniqueness in vv.10-11, it draws our attention back to verse 6 . Only someone who was "in the form of God" and "equal with God," could be worshipped and adored here at the end of the "hymn" and be given the divine name itself. The implications of vv.9-11 are so profound that if the one who is exalted was not previously in the form of God and equal to God then Paul would have ceased to be a monotheist. ${ }^{47}$ What is important about the movement from verse 6 to verse 11 then, is that Jesus is shown to be in eschatology what he always was in protology. Thus, we are able to speak of Jesus being God without inferring two Gods (and destroying monotheism) or numerically equating the Father and the Son (destroying the distinction of persons).

\section{Conclusion}

Having now analyzed key Scriptural passages concerning the Son's deity in addition to briefly discussing the Nicene creed, we hope to have confirmed the utility of an 'is' of predication in the strong sense. The aim of this work has been to introduce a sense of is that more precisely conveys what Christians mean when confessing: 'Jesus is God'. For understanding this confession according to an 'is' of numerical identity entails a denial of either monotheism or the distinctness of the persons. On the other hand, an 'is' of predication in the weak sense fails to affirm all that the Christian intends to affirm when confessing 'Jesus is God.' Therefore, a third sense of 'is' has been introduced - the 'is' of predication in the strong sense. This sense allows the Christian to coherently and fully affirm that Jesus, the Son of God, is God. We have seen that this approach employing an 'is' of predication in the strong sense is consistent with creedal and traditional expressions of orthodox

\footnotetext{
${ }^{47}$ This is so even as Paul's talk of the "one God" is flexible and fluid. See the helpful work on key Pauline passages where Paul expressly affirms that there is "one God" and yet Christ is brought into the divine identity (Nicholson 2011).
} 
Christian faith as well as the Scriptures that constitute the foundation of all constructive theology, including the doctrine of the Holy Trinity. ${ }^{48}$

\section{Bibliography}

Akala, Adesola Joan. 2014. The Son-Father Relationship and Christological Symbolism in the Gospel of John. LNTS 505. London: Bloomsbury/T\&T Clark.

Alston, William P. 2002. "Substance and the Trinity." In The Trinity: An Interdisciplinary Symposium on the Trinity, edited by Stephen T. Davis, Daniel Kendall SJ, and Gerald O'Collins SJ, 179-202. New York, NY: Oxford University Press. https://doi.org/10.1093/0199246122.003.0008.

Aquinas, Thomas. 1947. Summa Theologica. Benzinger Bros. edition. Translated by Fathers of the English Dominican Province.

Aristotle. 1984. "Categories." In The Complete Works of Aristotle: The Revised Oxford Translation, edited by Jonathan Barnes, 3-24. Princeton, NJ: Princeton University Press.

Aristotle. 1984. "Physics." In The Complete Works of Aristotle: The Revised Oxford Translation, edited by Jonathan Barnes, 315-446. Princeton, NJ: Princeton University Press.

Rettig, John W. (trans). 1988. St Augustine: Tractates on the Gospel of John 1-10. The Fathers of the Church: A New Translation. Volume 78. Washington, D.C.: The Catholic University of America Press.

Barth, Karl. 1956. Church Dogmatics. Volume IV, 1. Edinburgh: T\&T Clark.

Bauckham, Richard J. 2007. "Monotheism and Christology in the Gospel of John." In The Testimony of the Beloved Disciple: Narrative, History, and Theology in the Gospel of John, 239-52. Grand Rapids, MI: Baker.

Bauckham, Richard J. 2008. "God Crucified." In Jesus and the God of Israel: 'God Crucified' and other Studies on the New Testament's Christology of Divine Identity, 159. Milton Keynes, UK: Paternoster.

Beasley-Murray, George R. 1999. John. Word Biblical Commentary 36. 2nd edition. Nashville, TN: Thomas Nelson.

\footnotetext{
${ }^{48}$ Acknowledgements: The development of this article has benefited from feedback received at the Evangelical Theological Society Westcoast and Northwest meetings, as well as the Northwest Philosophy Conference and the Davenant Institute Northwest Convivium Irenicum. Owen would also like to thank Dale Tuggy for sending him a copy of 'How to Be a Monotheistic Trinitarian,' which Tuggy presented at the 2014 LA Theology Conference. Thanks are also due to Aryn Owen, Garry DeWeese, Fred Sanders, Steven Duby, Mihretu Guta and Dennis Bray for helpful conversations, as well as two anonymous referees for their insightful feedback.
} 
Beebee, Helen, Nikk Effingham, and Philip Goff (eds.). 2011. Metaphysics: The Key Concepts. New York, NY: Routledge.

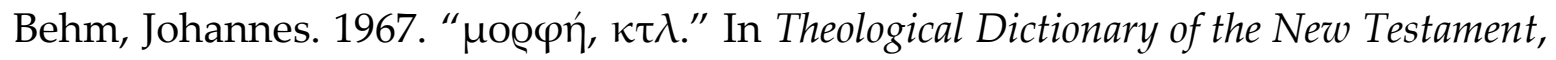
edited by Gerhard Kittel, translated by Geoffrey W. Bromiley, 4:742-59. Ten Volumes. Grand Rapids, MI: Eerdmans.

Bohn, Einar Duenger. 2011. "The Logic of the Trinity." Sophia 50.3: 363-74. https://doi.org/10.1007/s11841-011-0265-1.

Bockmuehl, Markus N. 1997. "The Form of God' (Phil. 2:6): Variations on a Theme of Jewish Mysticism." Journal of Theological Studies 48.1: 1-23. https://doi.org/10.1093/jts/48.1.1.

Brown, Christopher M. 2005. Aquinas and the Ship of Theseus: Solving Puzzles About Material Objects. New York, NY: Continuum.

Bultmann, Rudolf. 1968. Das Evangelium des Johannes. Kritisch-exegetischer Kommentar über das Neue Testament. Göttingen: Vandenhoeck \& Ruprecht.

Burk, Denny. 2004. "On the Articular Infinitive in Philippians 2:6: A Grammatical Note With Christological Implications." Tyndale Bulletin 55.2: 253-74.

Busch, Eberhard. 1975. Karl Barth: His life from letters and autobiographical texts. Translated by John Bowden. Eugene, OR: Wipf \& Stock.

Capes, David B. 1992. Old Testament Yahweh Texts in Paul's Christology. WUNT II/47. Tübingen: Mohr Siebeck.

Carson, D. A. The Gospel According to John. Pillar New Testament Commentary. Nottingham: Apollos / Grand Rapids, MI: Eerdmans, 1991.

Maxwell, David R. (trans.). 2013. Commentary on John: Cyril of Alexandria. Ancient Christian Texts. Volume 1. Edited by Joel C. Elowsky. Downer's Grove, IL: IVP.

Dunn, James D. G. 1988. Romans 9-16. Word Biblical Commentary 38b. Dallas, TX: Word.

Dunn, James D. G. 1998. The Theology of Paul the Apostle. Grand Rapids, MI: Eerdmans.

Edwards, Mark J. (ed.). 1999. Galatians, Ephesians, Philippians. Ancient Christian Commentary on Scripture. Volume VIII. Downer's Grove, IL: InterVarsity Press.

Fee, Gordon D. 1995. Paul's Letter to the Philippians. NICNT. Grand Rapids, MI: Eerdmans.

Fee, Gordon D. 2007. Pauline Christology: An Exegetical-Theological Study. Peabody, MA: Hendrickson.

Friedrich, Gerhard. 1981. "Der Brief an die Philipper." In J. Becker, H. Conzelmann, und G. Friedrich, Die Briefe an die Galater, Epheser, Philipper, Kolosser, Thessalonicher und Philemon, 125-75. Das Neue Testament Deutsch 8. Göttingen: Vandenhoeck \& Ruprecht. 
Gorman, Michael J. 2009. "Although/Because He Was in the Form of God: The Theological Significance of Paul's Master Story (Phil 2:6-11)." In Inhabiting the Cruciform God: Kenosis, Justification, and Theosis in Paul's Narrative Soteriology, 939. Grand Rapids, MI: Eerdmans.

Grelot, Pierre. 1973. “Deux Notes Critques sur Philippiens 2,6-11.” Biblica 54: 16986.

Harris, Murray J. 1992. Jesus as God: The New Testament Use of Theos in Reference to Jesus. Grand Rapids, MI: Baker.

Harner, Philip B. 1973. “Qualitative Anarthrous Predicate Nouns: Mark 15:39 and John 1:1." Journal of Biblical Literature 92.1: 75-87. https://doi.org/10.2307/3262756.

Heil, John. 2019. "The Mystery of the Mystery of Consciousness." In Consciousness and the Ontology of Properties, edited by Mihretu Guta, 15-23. New York, NY: Routledge.

Hellerman, Joseph H. 2005. Reconstructing Honor in Roman Philippi: Carmen Christi as Cursus Pudorum. SNTSMS 132. Cambridge: Cambridge University Press. https://doi.org/10.1017/CBO9780511487972.

Hengel, Martin. 2008. "The Prologue of the Gospel of John as the Gateway to Christological Truth." In The Gospel of John and Christian Theology, edited by Richard Bauckham and Carl Mosser, 265-94. Grand Rapids, MI: Eerdmans.

Hill, Wesley. 2015. Paul and the Trinity: Persons, Relations, and the Pauline Letters. Grand Rapids, MI: Eerdmans.

Hooker, Morna D. 1990. “Philippians 2.6-11." In From Adam to Christ: Essays on Paul, 88-100. Cambridge: Cambridge University Press.

Hoover, Roy W. 1971. "The Harpagmos Enigma: A Philological Solution." Harvard Theological Review 64: 95-119. https://doi.org/10.1017/S0017816000018058.

Holmes, Stephen R. 2014. “Classical Trinity: Evangelical Perspective." In Twos View on the Doctrine of the Trinity, edited by Jason S. Sexton, 25-48. Grand Rapids, MI: Zondervan.

Hughes, Christopher. 2009. "Defending the Consistency of the Doctrine of the Trinity." In Philosophical and Theological Essays on the Trinity, edited by Thomas McCall and Michael Rea, 293-313. New York: Oxford University Press.

Inman, Ross D. 2018. Substance and the Fundamentality of the Familiar: A NeoAristotelian Mereology. New York, NY: Routledge.

Keener, Craig S. 2003. The Gospel of John: A Commentary. 2 Volumes. Peabody, MA: Hendrickson.

Kleinschmidt, Shieva. 2016. "Simple Trinitarianism and Feature-Placing Sentences." Faith and Philosophy 33, 3: 257-277. https://doi.org/10.5840/faithphil201633365. 
Kleinschmidt, Shieva. 2018. "Simple Trinitarianism and empty names." Religious Studies 54, 3: 325-335. https://doi.org/10.1017/S0034412518000288

Klink, Edward W. 2016. John. Zondervan Exegetical Commentary on the New Testament 4. Grand Rapids, MI: Zondervan.

Köstenberger, Andreas J. and Scott R. Swain. 2008. Father, Son and Spirit: The Trinity and John's Gospel. New Studies in Biblical Theology 24. Nottingham: Apollos / Downer's Grove, IL: IVP.

Köstenberger, Andreas J., Benjamin L. Merkle, and Robert L. Plummer. 2016. Going Deeper with New Testament Greek: An Intermediate Study of the Grammar and Syntax of the New Testament. Nashville, TN: B\&H.

Lohmeyer, Ernst. 1964. Die Briefe an die Philipper, an die Kolosser und an Philemon. Kritisch-exegetischer Kommentar über das Neue Testament. Göttingen: Vandenhoeck \& Ruprecht.

Loux, Michael J. 2006. Metaphysics: A Contemporary Introduction. Third edition. New York, NY: Routledge. https://doi.org/10.4324/9780203968871.

Louw, Johannes P. and Eugene A. Nida. 1989. Greek-English Lexicon of the New Testament Based on Semantic Domains. Second Edition. Two Volumes. New York, NY: United Bible Societies.

Martin, Ralph P. 1967. Carmen Christi: Philippians II.5-11 in recent interpretation and in the setting of Early Christian Worship. SNTSMS 4. London: Cambridge University Press.

McCall, Thomas H. 2015. An Invitation to Analytic Christian Theology. Downer's Grove, IL: IVP Academic.

Metzger, Bruce M. 1994. A Textual Commentary on the Greek New Testament. Second Edition. Peabody, MA: Hendrickson.

Merricks, Trenton. 2006. "Split Brains and the Godhead." In Knowledge and Reality: Essays in Honor of Alvin Plantinga, edited by Thomas Crisp, David Vander Laan \& Matthew Davidson, 299-326. Kluwer Academic Publishers. https://doi.org/10.1007/1-4020-4733-9 13.

Moo, Douglas J. 1996. The Epistle to the Romans. New International Commentary on the New Testament. Grand Rapids, MI: Eerdmans.

Moreland, J. P. and William Lane Craig. 2003. Philosophical Foundations for a Christian Worldview. Downer's Grove, IL: IVP Academic.

Morris, Leon. 1995. The Gospel According to John. New International Commentary on the New Testament. Revised edition. Grand Rapids, MI: Eerdmans.

Muller, Richard A. 1985. A Dictionary of Latin and Greek Theological Terms: Drawn Principally From Protestant Scholastic Theology. Grand Rapids, MI: Baker Academic. 
Nicholson, Suzanne. 2011. Dynamic Oneness: The Significance and Flexibility of Paul's One-God Language. Cambridge: James Clarke \& Co.

Oakes, Peter. 2001. Philippians: From People to Letter. SNTSMS 110. Cambridge: Cambridge University Press.

Pelikan, Jaroslav and Valerie Hotchkiss. 2003. Creeds $\mathcal{E}$ Confessions of the Faith in the Christian Tradition. Volume 1: Early, Eastern, and Medieval. New Haven, CT: Yale University Press.

Rea, Michael C. 2003. "Relative Identity and the Doctrine of the Trinity." Philosophia Christi 5, 2: 431-435. https://doi.org/10.5840/pc20035247.

Robertson, A. T. 1934. A Grammar of the Greek New Testament in the Light of Historical Research. Nashville, TN: Broadman Press.

Schaff, Philip (ed.). 1994. Chrysostom: Homilies on Galatians, Ephesians, Philippians, Colossians, Thessalonians, Timothy, Titus, and Philemon. Nicene and Post-Nicene Fathers. Volume 13. Peabody, MA: Hendrickson.

Sanders, Fred. 2005. The State of the Doctrine of the Trinity in Evangelical Theology. Southwestern Journal of Theology 47, 2: 153-176.

Schulz, Siegfried. 1983. Das Evangelium nach Johannes. Das Neue Testament Deutsch 4. Göttingen: Vandenhoeck \& Ruprecht.

Silva, Moisés. 2005 [1992]. Philippians. Second Edition. Baker Exegetical Commentary on the New Testament. Grand Rapids, MI: Baker.

Sumney, Jerry L. Steward of God's Mysteries: Paul and Early Church Tradition. Grand Rapids, MI: Eerdmans, 2017.

Conti, Marco (trans.). 2010. Commentary on the Gospel of John: Theodore of Mopsuestia. Ancient Christian Texts. Edited by Joel C. Elowsky. Downer's Grove, IL: IVP.

Thompson, Marianne Meye. 2001. The God of the Gospel of John. Grand Rapids, MI: Eerdmans.

Thyen, Hartwig. 2005. Das Johannesevangelium. Handbuch zum Neuen Testament 6; Tübingen: Mohr Siebeck.

Tillman, Fritz. 1931. Das Johannesevangelium. Vierten Auflage. Die Heilige Schrift Des Neuen Testamentes. Bonn: Peter Hanstein Verlagsbuchhandlung.

Tuggy, Dale. 2014a. "How to be a Monotheistic Trinitarian." Unpublished paper presented at the $2^{\text {nd }}$ Annual Los Angeles Theology Conference on January 17, 2014. Pasadena, CA.

Tuggy, Dale. 2014b. "Podcast 24-How To Be a Monotheistic Trinitarian." Retrieved from Trinities.org: http://trinities.org/blog/podcast-episode-24-howto-be-a-monotheistic-trinitarian/ (accessed September 5, 2018).

Tuggy, Dale. 2016. "Metaphysics and Logic of the Trinity. In Oxford Handbooks Online. https://doi.org/10.1093/oxfordhb/9780199935314.013.27. 
van Inwagen, Peter. 1988. "And Yet They Are Not Three Gods But One God." In Philosophy and the Christian Faith, edited by Thomas V. Morris, 241-278. Notre Dame, Indiana: University of Notre Dame Press.

Wallace, Daniel B. 1996. Greek Grammar: Beyond the Basics: An Exegetical Syntax of the New Testament. Grand Rapids, MI: Zondervan.

Watson, Francis. 2000. "The Triune Divine Identity: Reflections on Pauline GodLanguage, in Disagreement with J. D. G. Dunn." Journal for the Study of the New Testament 80: 99-124.

Wright, N. T. 1993. The Climax of the Covenant: Christ and the Law in Pauline Theology. Minneapolis, MN: Fortress.

Wright, N. T. 2015 [2002]. "The Letter to the Romans: Introduction, Commentary, and Reflections." In The New Interpreter's Bible Commentary, Volume IX, edited by Leander E. Keck, 317-664. Revised edition. Nashville, TN: Abingdon. 